\title{
AMERICAN TRYPANOSOMIASIS AND ELECTROCARDIOGRAPHIC ALTERATIONS AMONG INDUSTRIAL WORKERS IN SÃO PAULO, BRAZIL
}

\author{
Moisés GOLDBAUM(1), Fabio Yoshito AJIMURA(1), Júlio LITVOC(1), Silvino Alves de CARVALHO(2) \& José ELUF-NETO(1)
}

\begin{abstract}
SUMMARY
In this article, we evaluate electrocardiographic (ECG) alterations among urban workers from a mechanical-metallurgical industry in São Paulo, Brazil. In a cross-sectional survey carried out in 1980, we found $2.2 \%$ positive serological testing for Trypanosoma cruzi infection among 27,081 workers. A comparison between seropositive workers and a random sample of seronegative workers frequency-matched by age and occupation revealed that seropositive workers had a much lower educational level, and that a higher proportion of seropositive workers had ECG abnormalities (42.7\%) when compared to those negative for T. cruzi infection (19.8\%). The high frequency of ECG abnormalities suggests the need to provide medical assistance to these workers, without any kind of discrimination and to bring in a form of management that would decrease this dangerous risk to the workers and people around them.
\end{abstract}

KEYWORDS: Chagas disease; Cardiomiopathy; Cross-sectional study; Industrial workers.

\section{INTRODUCTION}

American trypanosomiasis, also known as Chagas disease, is an endemic zoonosis caused by the protozoan parasite Trypanosoma cruzi ${ }^{6}$, whose life cycle involves mammalian hosts (including humans) and insect vectors (various species of triatomines ${ }^{5}$ ). This typical tropical disease is found throughout the American continent, from the south of Argentina to the south of the USA ${ }^{11}$. The process of urbanization occurring in Latin America has changed the geographic distribution of Chagas disease. This urbanization is also responsible for the development of newer and important ways of transmission.

A survey by the Pan American Health Organization indicates 16 to 18 million people infected with the parasite on the American continent and 90 million exposed to the risk of being infected ${ }^{13}$. In Brazil, it is estimated that about 5 million people were infected in the 1980's $\mathrm{s}^{8}$. Over recent decades, there has been a large increase in the number of infected people living in urban areas. This increase has been mainly due to migration from rural areas ${ }^{19}$, and secondarily to blood transfusion $^{16}$.

The most important clinical manifestation of Chagas disease is cardiac. Electrocardiographic (ECG) changes seem to be the most common heart alteration in this disease ${ }^{21}$. The great majority of studies on ECG changes among individuals infected with T. cruzi have been conducted in rural endemic areas or clinical settings ${ }^{7}$. The aim of the present research was to evaluate ECG alterations related to Chagas disease among urban workers in a mechanical-metallurgical industry. We also investigated whether time of residence in a rural area during the first five years of life was associated with ECG alterations.

\section{SUBJECTS AND METHODS}

A cross-sectional survey for American trypanosomiasis infection was carried out in 1980 among urban workers from a mechanicalmetallurgical industry of the Metropolitan Area of São Paulo, Brazil ${ }^{9}$. We screened 27,081 workers from this industry with a blood sample collected by finger prick onto filter paper; eluates were tested for antiTrypanosoma cruzi antibodies using immunofluorescence. The seropositive and a random sample of seronegative workers in the first test were invited to have a new blood sample collected by venopuncture. The seronegative (approximately 2:1) were frequency-matched to seropositive workers by age and occupation. Only eight women were seropositive; they were excluded. Participants were interviewed using a standardized questionnaire, and an electrocardiogram was performed, with five complex in median per derivation and a long D2 with twenty complex in median.

At a second stage, three serological tests for T. cruzi infection were performed on the blood samples: immunofluorescence ${ }^{2}$, hemagglutination ${ }^{3}$ and complement fixation ${ }^{18}$. Individuals found positive in two or three of the tests were considered seropositive for $T$. 
GOLDBAUM, M.; AJIMURA, F.Y.; LITVOC, J.; CARVALHO, S.A. \& ELUF-NETO, J. - American trypanosomiasis and electrocardiographic alterations among industrial workers in São Paulo, Brazil. Rev. Inst. Med. trop. S. Paulo, 46(6):299-302, 2004.

cruzi infection. Those negative in all three serological tests were classified as seronegative.

Electrocardiograms were recorded in 12 standard derivations (long D2) with the subject at rest. They were independently interpreted by two of us (MG, JEN), without knowledge of the serological status. In those cases involving disagreement between the two readers, electrocardiograms were reviewed by both to reach a final classification.

Chi-square for linear trend was used to test statistical significance between seropositive and seronegative workers according to educational level. To estimate the association between seropositive and ECG abnormalities, odds ratios (OR) with $95 \%$ confidence intervals $(95 \%$ CI) were calculated using non-conditional logistic regression ${ }^{1}$ (Stata Corp. Stata Statistical Software: Release 6.0. College Station, TX. Stata Corporation).

\section{RESULTS}

The first screening of the 27,081 workers found $591(2.2 \%)$ individuals with positive serological test onto filter paper for $T$. cruzi infection. At the second stage, we recovered 373 seropositive workers. The seropositive workers were slightly older $($ mean $=35.5$ years; median $=34.0)$ than the seronegative workers $($ mean $=34.2$; median $=33.0$ ). The distribution by age-group and educational level is shown in Table 1. Workers infected with Trypanosoma cruzi had a much lower educational level than seronegative workers $\left(\chi^{2}\right.$ for linear trend $=50.89$, $\mathrm{p}<0.001)$.

A higher proportion of seropositive workers had ECG abnormalities when compared to those negative for T. cruzi infection. Some alteration was found in $156(42.7 \%)$ of the seropositive and in $110(19.8 \%)$ of the seronegative cases (Table 2). A large difference was observed in all age groups, especially among workers less than 40 years old. The OR of any ECG abnormality associated with seropositivity, adjusted for age and educational level, was 3.05 (95\% CI 2.23 - 4.17).

Five types of ECG alteration (complete right bundle branch block - CRBB -, left anterior hemiblock - LAH -, ventricular extrasystoles VE -, $1^{\text {st }}$ degree A-V block $-1^{\text {st }} \mathrm{AVB}$ - ventricular repolarization alteration -VRA) were associated with $T$. cruzi infection after adjustment for age and educational level (Table 3). The strongest association was observed with CRBB $(\mathrm{OR}=34.40,95 \%$ CI $10.41-113.67)$. No other ECG
Table 1

Distribution of T. cruzi seropositive and seronegative workers by age and years of study

\begin{tabular}{lcccc}
\hline Age (years) & $\begin{array}{c}\text { Seronegative workers } \\
\text { N }\end{array}$ & $(\%)$ & Seropositive & workers \\
& & 13.0 & 25 & 6.7 \\
\hline $15-24$ & 75 & 19.8 & 75 & 20.1 \\
$25-29$ & 114 & 24.0 & 89 & 23.9 \\
$30-34$ & 138 & 15.8 & 73 & 19.6 \\
$35-39$ & 91 & 12.1 & 52 & 13.9 \\
$40-44$ & 70 & 9.4 & 36 & 9.6 \\
$45-49$ & 54 & 5.9 & 23 & 6.2 \\
$50+$ & 34 & 100.0 & 373 & 100.0 \\
Total & 576 & & & \\
\hline Years of study* & & 14.8 & 119 & 31.9 \\
\hline$<4$ & 85 & 49.1 & 186 & 49.9 \\
4 & 282 & 15.9 & 39 & 10.5 \\
$5-7$ & 91 & 9.8 & 13 & 3.5 \\
8 & 56 & 10.5 & 16 & 4.3 \\
$>8$ & 60 & 100.0 & 373 & 100.0 \\
Total & 574 & & & \\
\hline
\end{tabular}

*Data missing for two seronegative workers; $\mathrm{p}<0.001$.

Table 2

Frequency of any ECG alteration* among seropositive and seronegative workers according to age

\begin{tabular}{lcccccc}
\hline & \multicolumn{3}{c}{ Seronegative } & \multicolumn{3}{c}{ Seropositive } \\
Age & Number & ECG alteration & Number & ECG alteration \\
(years) & & $\mathrm{N}$ & $(\%)$ & & $\mathrm{N}$ & $(\%)$ \\
\hline $15-24$ & 72 & 13 & 18.1 & 25 & 14 & 56.0 \\
$25-29$ & 107 & 26 & 24.3 & 73 & 27 & 37.0 \\
$30-34$ & 133 & 17 & 12.8 & 88 & 36 & 40.9 \\
$35-39$ & 89 & 12 & 13.5 & 70 & 29 & 41.4 \\
$40-44$ & 69 & 12 & 17.4 & 52 & 16 & 30.8 \\
$45-49$ & 53 & 20 & 37.7 & 34 & 22 & 64.7 \\
$50+$ & 33 & 10 & 30.3 & 23 & 12 & 52.2 \\
Total & 556 & 110 & 19.8 & 365 & 156 & 42.7 \\
\hline
\end{tabular}

* Data for electrocardiogram missing for 20 seronegative and eight seropositive workers.

Table 3

Prevalence of ECG alteration in industrial workers according to the Trypanosoma cruzi serology

\begin{tabular}{lccccccc}
\hline ECG & \multicolumn{2}{c}{ Seronegative } & \multicolumn{2}{c}{ Seropositive } & Odds ratio & Odds ratio* & 95\% CI \\
& $\mathrm{N}$ & $(\%)$ & $\mathrm{N}$ & $(\%)$ & & & \\
\hline CRBB & 3 & 0.5 & 53 & 14.5 & 31.31 & 34.40 & $(10.41-113.67)$ \\
LAH & 7 & 1.3 & 11 & 3.0 & 2.44 & 2.01 & $(0.74-5.41)$ \\
VE & 10 & 1.8 & 33 & 9.0 & 5.43 & 6.04 & $(2.85-12.79)$ \\
$1^{\text {st }}$ AVB & 3 & 0.5 & 16 & 4.4 & 8.45 & 9.11 & $(2.49-33.38)$ \\
VRA & 10 & 1.8 & 19 & 5.2 & 3.00 & 2.73 & $(1.19-6.26)$ \\
ANY & 110 & 19.8 & 156 & 42.7 & 3.03 & 3.03 & $(2.23-4.17)$ \\
\hline
\end{tabular}

* Adjusted for age and educational level; $\mathrm{CRBB}=$ complete right bundle branch block; $\mathrm{LAH}=$ left anterior hemiblock; $\mathrm{VE}=$ ventricular extrasystoles; $1^{\text {st }} \mathrm{AVB}=1^{\text {st }}$ degree $\mathrm{A}-\mathrm{V}$ block; VRA = ventricular repolarization alteration; $\mathrm{ANY}=$ any alteration. 
alteration type was found with a significant difference between seropositive and seronegative individuals. We did not observe inactive myocardial areas.

A possible effect of time spent living in an endemic area for heart damage was investigated in the seropositive group. The presence of any ECG abnormality did not differ according to the number of years spent in a rural region during the first five (Table 4) or ten years of life (data not shown). Nor was any association either was found with regard to the most frequent ECG alterations.

Table 4

Time of residence in rural area within the first five years of life and prevalence of any ECG alterations among seropositives*

\begin{tabular}{ccc}
\hline Number of years & Total & ECG alterations N (\%) \\
\hline 0 & 47 & $19(40.4)$ \\
1 & 1 & $0(0.0)$ \\
2 & 8 & $5(62.5)$ \\
3 & 7 & $4(57.1)$ \\
4 & 8 & $4(50.0)$ \\
5 & 287 & $120(41.8)$ \\
\hline
\end{tabular}

*Data missing for 15 individuals.

\section{DISCUSSION}

Cardiopathies are the most important manifestations of Chagas disease and they can be measured by the electrocardiogram. Many studies have shown that there are strong associations between certain specific alterations and this trypanosomiasis ${ }^{4,8,12,14}$. The findings in this study agree with earlier research in the field demonstrating a statistically significant higher prevalence of any kind of ECG abnormality in seropositive than in seronegative for $T$. cruzi infection. The specific types of ECG alterations related to the infection were VE, CRBB, LAH, $1^{\text {st }}$ AVB and VRA. We found higher prevalence of ECG alterations in all age groups. The high prevalence of ECG alterations in seropositive workers under 40 years of age confirms a relatively short incubation period for development of chronic Chagas cardiomyopathy.

Specifically, CRBB is the most characteristic alteration in the electrocardiogram of individuals with Chagas cardiopathy. In addition, this alteration has a great importance because it represents, among others one of the leading cause of mortality ${ }^{14}$.

We detected that urban workers infected with T. cruzi have precocious ECG alterations when compared with seronegative workers. These alterations are of particular importance since they are, frequently, the first manifestations of Chagas disease, although they do not lead to clinical symptoms. In this situation, healthy urban workers infected with $T$. cruzi could be unaware of their clinical status, especially the cardiac. Exposure to heavy and dangerous activity at work could worsen the course of the disease ${ }^{10}$.

Our study corroborates previous data indicating that seropositives for $T$. cruzi have a higher risk of developing ECG alterations and, consequently, cardiopathy. Regarding the association of the infection with poor social-economic conditions, measured by educational level, these people are exposed to hard working conditions, especially in urban areas. We have shown that workers infected with Trypanosoma cruzi had a much lower educational level than seronegative workers. This confirms previous observations.

A few factors have been postulated for the development of Chagas cardiopathy in infected individuals, including immunological factors, reinfections and physical exertion. MAGUIRE et al. ${ }^{12}$ investigated the possible effect of physical activity and time of residence in rural areas for the development of Chagas cardiopathy. We tried to correlate time of residence in an rural area (rural area considered as an indirect marker of an endemic area for Chagas disease) and cardiopathy, as measured by electrocardiogram, since more time in such area would lead to higher levels of parasitemia and a greater possibility of developing cardiopathy related to trypanosomiasis. According to these data, presence of positive epidemiological data, such as living in an endemic area in the earliest years of life, could be a reason for treatment, decreasing the viral load and the parasitemia, leading to less alteration in the cardiac muscle ${ }^{20}$. However, in this survey, in agreement to MAGUIRE et $a l .{ }^{12}$, we determined that the number of years spent in an endemic region during the first five or ten years of life was not associated with cardiac manifestations, as indicated by ECG abnormality.

In conclusion, the high frequency of those manifestations found suggests the necessity of providing medical assistance to these workers ${ }^{15,17}$, without any kind of discrimination, and of bringing in a form of management that would decrease dangerous risk to the worker and the people around them.

\section{RESUMO}

\section{Doença de Chagas e alterações eletrocardiográficas entre trabalhadores industriais em São Paulo, Brasil}

Neste artigo, analisamos a freqüência de alterações eletrocardiográficas (ECG) em trabalhadores de indústria mecânico-metalúrgica de São Paulo, Brasil. Num estudo transversal, conduzido em 1980, encontramos $2,2 \%$ de reações sorológicas positivas para infecção pelo Trypanosoma cruzi entre 27.081 trabalhadores. Uma comparação entre trabalhadores soropositivos e uma amostra aleatória de trabalhadores soronegativos pareados por freqüência em idade, e ocupação mostrou que os trabalhadores soropositivos apresentam menor nível de escolaridade e maior proporção de alterações ECG (42.7\%) quando comparados aos soronegativos para infecção pelo T. cruzi (19.8\%). A alta freqüência de alterações ECG sugere a necessidade de oferecer assistência médica para esses trabalhadores, destituída de qualquer tipo de discriminação, criando condições para diminuir os riscos para esses trabalhadores e os indivíduos próximos.

\section{REFERENCES}

1. BRESLOW, N.E. \& DAY, N.E. - Statistical methods in cancer research: the analysis of case-control studies. Lyon, International Agency for Research on Cancer, 1980. v. 1. (Publication No. 32)

2. CAMARGO, M.E. - Fluorescent antibody test for the serodiagnosis of American Trypanosomiasis. Technical modification employing preserved culture forms of Trypanosoma cruzi in a slide test. Rev. Inst. Med. trop. S. Paulo, 8: 227-234, 1966.

3. CAMARGO, M.E.; HOSHINO, S. \& SIQUEIRA, G.R.V. - Hemagglutination with 
GOLDBAUM, M.; AJIMURA, F.Y.; LITVOC, J.; CARVALHO, S.A. \& ELUF-NETO, J. - American trypanosomiasis and electrocardiographic alterations among industrial workers in São Paulo, Brazil. Rev. Inst. Med. trop. S. Paulo, 46(6):299-302, 2004.

preserved sensitized cells, a practical test for routine serologic diagnosis of American trypanosomiasis. Rev. Inst. Med. trop. S. Paulo, 15: 81-85, 1973.

4. CASTRO, C.; PRATA, A. \& MACEDO, V. - Estudo clínico durante 13 anos de 190 chagásicos crônicos de Mambaí, Goiás, Brasil. Rev. Soc. bras. Med. trop., 34: 309318,2001

5. CARVALHO, M.E.; SILVA, R.A.; RODRIGUES, V.L.C.C. \& OLIVEIRA, C.D. Programa de controle da doença de Chagas no Estado de São Paulo: sorologia de moradores como parte de investigação de unidades domiciliares com presença de triatomíneos vetores na década de 1990. Cadern. Saúde públ. (Rio de J.), 18: 1695$1703,2002$.

6. CHAGAS, C. - Nova tripanozomiaze humana: estudos sobre a morfologia e o ciclo evolutivo do Schizotrypanum cruzi n. gen., $n$. sp., ajente etiolójico de nova entidade mórbida do homem. Mem. Inst. Oswaldo Cruz, 1: 159-218, 1909.

7. COURA, J.R.; BORGES-PEREIRA, J.; ALVES FILHO, F.I. et al. - Morbidity of Chagas' disease in areas of Sertão da Paraiba and Caatinga do Piaui. Rev. Soc. bras. Med. trop., 29: 197-205, 1996.

8. FERREIRA, M.S.; LOPES, E.R.; CHAPADEIRO, E.; DIAS, J.C.P. \& OSTERMAYER, A.L. - Doença de Chagas. In: VERONESI, R. Tratado de Infectologia. São Paulo, Atheneu, 1996. p. 1175-1213.

9. GOLDBAUM, M. - Saúde e trabalho: a doença de Chagas no setor industrial. São Paulo, 1981. (Tese de doutorado - Faculdade de Medicina da Universidade de São Paulo).

10. GUARIENTO, M.E.; CAMILO, M.V.F. \& CAMARGO, A.M.A. - Working conditions of Chagas' disease patients in a large Brazilian city. Cadern. Saúde públ. (Rio de J.), 15: 381-386, 1999.

11. KIRCHOFF, L.V. - American trypanosomiasis (Chagas' disease): a tropical disease now in the United States. New Eng. J. Med., 329: 639-644, 1993.

12. MAGUIRE, J.H.; HOFF, R.; SHERLOCK, I. et al. - Cardiac morbidity and mortality due to Chagas' disease: prospective electrocardiographic study of a Brazilian community. Circulation, 75: 1140-1145, 1987.
13. PAN AMERICAN HEALTH ORGANIZATION - Health conditions in the Americas. Washington, PAHO, 1994. p. 147-149. (Scientific Publication No. 549)

14. PRATA, S.P.; CUNHA, D.F.; CUNHA, S.S.F.; PRATA, S.C. \& NOGUEIRA, N. Prevalência de alterações eletrocardiográficas em 2000 pacientes chagásicos idosos e não idosos. Arq. bras. Cardiol., 60: 369-372, 1993.

15. RAMOS Jr., N.A. \& CARVALHO, D.M. - Os diferentes significados da certificação conferida ao Brasil como estando livre da doença de Chagas. Cadern. Saúde públ. (Rio de J.), 17: 1403-1412, 2001.

16. SALLES, N.A.; SABINO, E.C.; CLIQUET, M.G. et al. - Risk of exposure to Chagas' disease among seroreactive Brazilian blood donors. Transfusion, 36: 969-973, 1996.

17. UCHOA, E.; FIRMO, J.O.A.; DIAS, E.C.; PEREIRA, M.S.N. \& GONTIJO, E.D. - Signos e significados e ações associadas à doença de Chagas. Cadern. Saúde públ. (Rio de J.), 18: 71-79, 2002

18. WADSWORTH, A.B.; MALTANER, F. \& MALTANER, E. - The quantitative determination of the fixation of complement by immune serum and antigen. $\mathbf{J}$. Immunol., 21: 313-340, 1931.

19. WANDERLEY, D.M. \& CORREA, F.M. - Epidemiology of Chagas' heart disease. Rev. paul. Med., 113: 742-749, 1995.

20. ZHANG, L. \& TARLETON, R.L. - Parasite persistence correlates with disease severity and localization in chronic Chagas' disease. J. infect. Dis., 180: 480-486, 1999.

21. ZICKER, F.; NETTO, J.C.A.N.; ZICKER, S.E.M.; OLIVEIRA, R.M. \& SMITH, P.G. Trypanosoma cruzi infection and eletrocardiographic findings among active manual workers. A population-based study in Central Brazil. Int. J. Epidem., 19: 182-186, 1990.

Received: 26 April 2004

Accepted: 6 October 2004 